\title{
Applications and Uncertainty Estimation of Single Level Standard Addition Method ICP-MS for Elemental Analysis in Various Matrix
}

\author{
Yanbei ZhU, ${ }^{* 1 \dagger}$ Kazumi NAKAno, ${ }^{* 2}$ Zhongyuan WANG, ${ }^{* 3}$ Yasuyuki ShIKAMORI, ${ }^{2}$ Koichi ChIBA, ${ }^{* 4}$ \\ Takayoshi KUroIwA, ${ }^{* 1}$ Akiharu HIOKI,*1 and Kazumi INAGAKI*1 \\ *1 National Metrology Institute of Japan (NMIJ), National Institute of Advanced Industrial Science and \\ Technology (AIST), 1-1-1 Umezono, Tsukuba, Ibaraki 305-8563, Japan \\ *2 Agilent Technologies Japan, Ltd., 9-1 Takakura, Hachioji, Tokyo 192-8510, Japan \\ *3 South China Sea Environment Monitoring Center, State Oceanic Administration, 155 Xingang West Road, \\ Guangzhou 510300, China \\ *4 Graduate School of Science and Technology, Kwansei Gakuin University, 1-1-155 Uegahara, Nishinomiya, \\ Hyogo 662-8501, Japan
}

\begin{abstract}
The standard addition method (SAM) based on gravimetric sample preparation was investigated as an approach for the removal or cancelling of matrix effects in measurements by inductively coupled plasma mass spectrometry (ICP-MS). Deduction of the equations and experimental confirmation of the method are both given in the present work. After measuring both spiked and non-spiked samples by ICP-MS, the concentration of an element could be calculated based on the signal intensity ratio to an internal standard. A practical example was provided for the measurement of Fe in a certified reference material (CRM), i.e. NMIJ CRM 7512-a (milk powder). The validity of the method had been confirmed by the results of international comparisons with various kinds of matrix, including bioethanol, human serum, biodiesel fuel, drinking water, infant formula milk power, and seafood. The suggested method had been applied to measurements of multiple elements in three CRMs, including tap water, milk powder, and tea leave powder, respectively.
\end{abstract}

Keywords ICP-MS, matrix effect, standard addition, internal standard, uncertainty

(Received January 31, 2018; Accepted March 13, 2018; Published June 10, 2018)

\section{Introduction}

These days, inductively coupled plasma mass spectrometry (ICP-MS) is the most popular approach for elemental analysis in various kinds of samples including chemical, material, environmental, biological, clinical, food, beverage, and so on, ${ }^{1-3}$ which could be attributed to the merits of ICP-MS for simultaneous multi-element analysis, wide linearity range, highly sensitive measurements, and better selectivity than that provided by optical analysis. On the other hand, the development of novel ICP-MS instruments has slowed down in recent years, ${ }^{4}$ which could be partly attributed to the fact that the line-up of instruments produced by various producers have provided enough selections for users.

Accurate and precise quantitation of the elements are often required for analysis using ICP-MS. For these purpose, strategies for the removal or cancelling of matrix effects in practical samples are often necessary for the analysis.5,6 According to International Union of Pure and Applied Chemistry (IUPAC), the matrix effect in analytical chemistry is defined as "the combined effect of all components of the sample other than the analyte on the measurement of the quantity". In the analysis

$\dagger$ To whom correspondence should be addressed.

E-mail: yb-zhu@aist.go.jp by ICP-MS, matrix effects could be classified as matrix-induce spectral overlap problems and matrix-induced signal intensity changes,$^{6}$ or their equivalents, i.e. translational matrix effect and rotational matrix effect, ${ }^{8}$ respectively.

Translational matrix effects in analysis by ICP-MS are caused by the spectral interferences from the sample matrix, which could be resolved by using high-resolution (HR-) ICP-MS, reaction cell technique, and chemical separation. In recent years, it has been notable that the availability of ICP-MS with a tandem quadrupole mass spectrometer and a reaction cell system have provided an effective approach for the removal of translational matrix effects.

On the other hand, rotational matrix effects are intensity changes caused by the sample matrix, due to differences in the sample up-take efficiency to the plasma, ionization in the plasma, ion extraction through the interface, and ion transport through the ion optics to the detector. ${ }^{5}$ There are several candidate strategies for the removal or cancelling of the rotational matrix effects:

(a) Optimization of the operating conditions of the ICP-MS or the use of mixed gas techniques: it could suppress rotational matrix effects to some extent, but may not be removed or completely cancelled. ${ }^{9-19}$

(b) Dilution of the sample or flow injection: this is effective by reducing the sample quantity loaded to the ICP-MS, but the application might depend on the concentration of 
the measurand or require additional instrument for flow injection. ${ }^{20-22}$

(c) Chemical separation: it is effective, but often requires additional separation operations. . $^{23-25}$

(d) Internal standard correction: it is effective to cancel the rotational matrix effect only if an internal standard is available having the same spectroscopic properties of a measurand in the measurement by ICP-MS. ${ }^{26,27}$

(e) Isotope dilution: it could be regarded as being a special case for (c) an internal standard correction, i.e. by using an enriched isotope of the measurand as the internal standard so as to ensure an identical activity of the internal standard and the measurand. The limitation is that enriched isotopes are often expensive, and it is not applicable to mono-isotope elements. ${ }^{28-30}$

(f) Matrix matching calibration standard: this is effective for cancelling the rotational matrix effect. However, it is often difficult to make calibration standards to completely matching the matrix of various practical samples. Any impurities in the solution for the making matrix matched standard limit the application. ${ }^{31}$

(g) Standard addition method (SAM): it is effective for cancelling the rotational matrix effect. It is notable that SAM had been suggested by IUPAC as an effective strategy for the matrix effect. ${ }^{32}$ It could be regarded as being a special case of (f) matrix matching calibration standard, i.e. using a practical sample as the matrix for making the calibration standard. Multiple standard-added samples were commonly required in classical ways, which gave an impression of laborious sample preparation.

Based on a survey of scientific papers, available through the database of Web of Science, there are over 10 papers that cooperate SAM and ICP-MS published per year in this past decade. The applications cover research fields of biology, ${ }^{33-35}$ cosmetics, ${ }^{36-38}$ energy, ${ }^{39-41}$ the environment, ${ }^{42-44}$ food, ${ }^{45-47}$ geology, ${ }^{48-50}$ industry, ${ }^{51-53}$ material,,${ }^{54-56}$ and plants. ${ }^{57-59}$

The development and application of SAM in these studies proved that SAM is an effective approach for the removal or cancelling of rotational matrix effects in measurements by ICPMS. On the other hand, the preparation of samples for SAM in a classical way, multiple concentration levels added to the sample, was often thought to be both laborious and timeconsuming. Actually, the earliest idea of SAM, suggested by Hans Hohn in 1937 for polarography, was based on a single level addition approach and had been applied for decades. ${ }^{60}$ Later development and application of SAM to fluorescent X-ray analysis had introduced multiple concentration levels addition (i.e. successive dilutions) to improve the accuracy of the measurement. ${ }^{61}$

According to the IUPAC document, when the linearity of the calibration curve could be ensured, a single level addition could be applied to the SAM for quantitative analysis. ${ }^{32}$ Therefore, single level addition SAM could be a practical approach for ICP-MS analysis, by taking into consideration the fact that the majorities of present commercial ICP-MS instruments could provide signal intensities for the elements covering a linearity range of even over nine orders of magnitude.

In a previous study by the present authors, a single level addition SAM approach had been proposed for the analysis by ICP-MS that considered the condition that an internal standard was used both in the standard and the sample, which required the concentration of the internal standard to be known both in the sample and in the standard. ${ }^{62}$ In the present work, a simplified and more practical single-level addition SAM was suggested as an effective strategy to remove or to cancel any rotational matrix effects in the analysis by ICP-MS, which permitted the use of an element in the sample with an unknown concentration as the internal standard. This is a big advantage because it permitted one to use an element that naturally occurred in the sample as the internal standard. Furthermore, by taking into consideration the fact that evaluation and report of the uncertainty is one of the principal issues for chemical quantitative analysis, the present work provides detailed examples for a practical calculation of each parameter, contributing to the uncertainty of the results. Such kinds of examples had been rarely reported up to now.

\section{Theoretical}

From the viewpoints of precision for sample pretreatment, all of the sample pretreatments in the present work were carried out based on a gravimetric method. For example, $0.5 \mathrm{~mL}$ of a solution sample taken with an A-grade pipette would result in a tolerable uncertainty of $0.005 \mathrm{~mL}$, giving a relative uncertainty of $1 \% .^{63}$ By contrast, $0.5 \mathrm{~g}$ of a solution sample taken with an electronic balance could provide a standard uncertainty of $0.0001 \mathrm{~g}$, or even lower, giving a relative uncertainty of $0.02 \%$, the precision for which could be improve by 50 -fold compared to a pretreatment using volumetric methods.

Equations for the calculation in SAM will be deduced as follows for the convenience of discussion on uncertainty considerations and calculations. All of the parameters used in deducing of the equations are summarized in Table 1. In addition to the element of interest (element $\mathrm{x}$ ), an internal standard element (element y) will also be measured as an approach to correct the signal drift during the ICP-MS measurement.

In the linearity range of the ICP-MS measurement, the relationship between the signal intensity and the concentration for element $\mathrm{x}$ and $\mathrm{y}$ in a sample could be expressed with Eqs. (1) and (2), respectively. After subtraction of the blank, i.e. $b_{\mathrm{x}}$ and $b_{y}$, the net signal intensity given by Eqs. (3) and (4) could be obtained from Eqs. (1) and (2), respectively.

$$
\begin{aligned}
& { }^{\mathrm{x}} S_{\mathrm{sam}}=a_{\mathrm{x}} \times{ }^{\mathrm{x}} c_{\mathrm{sam}}+b_{\mathrm{x}}, \\
& { }^{\mathrm{y}} S_{\mathrm{sam}}=a_{\mathrm{y}} \times{ }^{\mathrm{y}} c_{\mathrm{sam}}+b_{\mathrm{y}}, \\
& { }^{\mathrm{x}} S_{\text {sam }}^{\prime}=a_{\mathrm{x}} \times{ }^{\mathrm{x}} c_{\mathrm{sam}}, \\
& { }^{\mathrm{y}} S_{\text {sam }}^{\prime}=a_{\mathrm{y}} \times{ }^{\mathrm{y}} c_{\mathrm{sam}} .
\end{aligned}
$$

The ratio of the net signal intensity of element $\mathrm{x}$ to that of element $\mathrm{y}$ in the sample, i.e. non-spiked sample, could obtained by dividing Eq. (3) with Eq. (4) and be expressed as

$$
R_{\mathrm{sam}}=\frac{{ }^{\mathrm{x}} S_{\mathrm{sam}}^{\prime}}{{ }^{\mathrm{y}} S_{\mathrm{sam}}^{\prime}}=\frac{a_{\mathrm{x}} \times{ }^{\mathrm{x}} c_{\mathrm{sam}}}{a_{\mathrm{y}} \times{ }^{\mathrm{y}} c_{\mathrm{sam}}} .
$$

If a standard addition sample, i.e. a spiked sample, was obtained by mixing $m_{\text {sam }}(\mathrm{g})$ of the sample and $m_{\text {std }}(\mathrm{g})$ of the standard in which the concentration of elements $\mathrm{x}$ and $\mathrm{y}$ were ${ }^{\mathrm{x}} c_{\text {std }}$ and 0 , respectively, the concentration of elements $\mathrm{x}$ and $\mathrm{y}$ in this spiked sample could be expressed by Eqs. (6) and (7), respectively:

$$
{ }^{\mathrm{x}} c_{\mathrm{spk}}=\frac{m_{\mathrm{sam}} \times{ }^{\mathrm{x}} c_{\mathrm{sam}}+m_{\mathrm{std}} \times{ }^{\mathrm{x}} c_{\mathrm{std}}}{m_{\mathrm{sam}}+m_{\mathrm{std}}},
$$


Table 1 Parameters used in the equations for standard addition

\begin{tabular}{|c|c|c|c|}
\hline Parameter & Meaning & Parameter & Meaning \\
\hline${ }^{\mathrm{x}} S_{\mathrm{sam}}$ & $\begin{array}{l}\text { Signal intensity of the element of interest in the sample, } \\
\text { CPS. }\end{array}$ & ${ }^{\mathrm{y}} S_{\mathrm{sam}}$ & $\begin{array}{l}\text { Signal intensity of the internal standard in the sample, } \\
\text { CPS. }\end{array}$ \\
\hline$a_{\mathrm{x}}$ & $\begin{array}{l}\text { Slope of the calibration curve for the element of } \\
\text { interest. }\end{array}$ & $a_{\mathrm{y}}$ & Slope of the calibration curve for the internal standard. \\
\hline${ }^{\mathrm{x}} c_{\mathrm{sam}}$ & $\begin{array}{l}\text { Concentration of the element of interest in the sample, } \\
\mu \mathrm{g} \mathrm{g}^{-1} \text {. }\end{array}$ & ${ }^{\mathrm{y}} C_{\mathrm{sam}}$ & Concentration of internal standard in the sample, $\mu \mathrm{g} \mathrm{g}^{-1}$. \\
\hline$b_{\mathrm{x}}$ & $\begin{array}{l}\text { Intercept of the calibration curve for the element of } \\
\text { interest. }\end{array}$ & $b_{\mathrm{y}}$ & Intercept of the calibration curve for the internal standard. \\
\hline${ }^{\mathrm{x}} S_{\mathrm{sam}}^{\prime}$ & $\begin{array}{l}\text { Signal intensity of the element of interest in the sample, } \\
\text { CPS. }\end{array}$ & ${ }^{\mathrm{y}} S_{\mathrm{sam}}^{\prime}$ & $\begin{array}{l}\text { Signal intensity of the internal standard in the sample, } \\
\text { CPS. }\end{array}$ \\
\hline$m_{\text {sam }}$ & Mass of the sample for making the spiked sample. & $m_{\text {std }}$ & Mass of the standard for making the spiked sample. \\
\hline${ }^{\mathrm{x}} C_{\mathrm{spk}}$ & $\begin{array}{l}\text { Concentration of the element of interest in the spiked } \\
\text { sample, } \mu \mathrm{g} \mathrm{g}^{-1} \text {. }\end{array}$ & ${ }^{\mathrm{y}} C_{\mathrm{spk}}$ & $\begin{array}{l}\text { Concentration of the internal standard in the spiked } \\
\text { sample, } \mu \mathrm{g} \mathrm{g}^{-1} \text {. }\end{array}$ \\
\hline$R_{\text {sam }}$ & $\begin{array}{l}\text { Signal intensity ratio of the element of interest to the } \\
\text { internal standard in the sample. }\end{array}$ & $R_{\mathrm{spk}}$ & $\begin{array}{l}\text { Signal intensity ratio of the element of interest to the } \\
\text { internal standard in the spiked sample. }\end{array}$ \\
\hline${ }^{\mathrm{x}} C_{\text {std }}$ & $\begin{array}{l}\text { Concentration of the element of interest in the standard, } \\
\mu \mathrm{g} \mathrm{g}^{-1} \text {. }\end{array}$ & ${ }^{\mathrm{x}} C_{\text {sld }}$ & $\begin{array}{l}\text { Concentration of the element of interest in the solid } \\
\text { sample, } \mu \mathrm{g} \mathrm{g}^{-1} \text {. }\end{array}$ \\
\hline$m_{\mathrm{sin}}$ & Mass of sample solution obtained after digestion, $\mathrm{g}$. & $m_{\mathrm{sld}}$ & Mass of solid sample taken for digestion, $\mathrm{g}$. \\
\hline$m_{\mathrm{dln}}$ & Mass of sample solution obtained after dilution, $\mathrm{g}$. & $m_{\mathrm{tkn}}$ & Mass of sample solution taken for dilution. \\
\hline$D$ & Dry mass correction factor. & $d$ & Signal drift observed in the measurement by ICP-MS. \\
\hline$r$ & Reproducibility of the experiment. & $B$ & Procedure blank, $\mu \mathrm{g} \mathrm{g}^{-1}$. \\
\hline
\end{tabular}

$$
{ }^{\mathrm{y}} C_{\mathrm{spk}}=\frac{m_{\mathrm{sam}} \times{ }^{\mathrm{y}} c_{\mathrm{sam}}}{m_{\mathrm{sam}}+m_{\mathrm{std}}} .
$$

Therefore, the ratio of the net signal intensity of element $x$ to that of element $y$ in this spiked sample could be expressed by

$$
\begin{aligned}
R_{\mathrm{spk}} & =\frac{{ }^{\mathrm{x}} S_{\mathrm{spk}}^{\prime}}{{ }^{\mathrm{y}} S_{\mathrm{spk}}^{\prime}}=\frac{a_{\mathrm{x}} \times{ }^{\mathrm{x}} c_{\mathrm{spk}}}{a_{\mathrm{y}} \times{ }^{\mathrm{y}} c_{\mathrm{spk}}}=\frac{a_{\mathrm{x}} \frac{m_{\mathrm{sam}} \times{ }^{\mathrm{x}} c_{\mathrm{sam}}+m_{\mathrm{std}} \times{ }^{\mathrm{x}} c_{\mathrm{std}}}{m_{\mathrm{sam}} \times m_{\mathrm{std}}}}{a_{\mathrm{y}} \frac{m_{\mathrm{sam}} \times{ }^{\mathrm{y}} c_{\mathrm{sam}}}{m_{\mathrm{sam}} \times m_{\mathrm{std}}}} \\
= & \frac{a_{\mathrm{x}}\left(m_{\mathrm{sam}} \times{ }^{\mathrm{x}} c_{\mathrm{sam}}+m_{\mathrm{std}} \times{ }^{\mathrm{x}} c_{\mathrm{std}}\right)}{a_{\mathrm{x}} \times m_{\mathrm{sam}} \times{ }^{\mathrm{y}} c_{\mathrm{sam}}} .
\end{aligned}
$$

The following equations could be obtained by dividing Eq. (5) with Eq. (8):

$$
\begin{aligned}
\frac{R_{\text {sam }}}{R_{\text {spk }}}= & \frac{\frac{a_{\mathrm{x}} \times{ }^{\mathrm{x}} c_{\text {sam }}}{a_{\mathrm{y}} \times{ }^{\mathrm{y}} c_{\text {sam }}}}{\frac{a_{\mathrm{x}}\left(m_{\mathrm{sam}} \times{ }^{\mathrm{x}} c_{\mathrm{sam}}+m_{\mathrm{std}} \times{ }^{\mathrm{x}} c_{\text {std }}\right)}{a_{\mathrm{y}} \times m_{\mathrm{sam}} \times{ }^{\mathrm{y}} c_{\text {sam }}}} \\
= & \frac{{ }^{\mathrm{x}} c_{\text {sam }} \times m_{\text {sam }}}{m_{\mathrm{sam}} \times{ }^{\mathrm{x}} c_{\text {sam }}+m_{\mathrm{std}} \times{ }^{\mathrm{x}} c_{\text {std }}} .
\end{aligned}
$$

Finally, we obtained Eq. (10) by rearrangement of Eq. (9):

$$
{ }^{\mathrm{x}} c_{\mathrm{sam}}=\frac{m_{\mathrm{std}} \times{ }^{\mathrm{x}} c_{\mathrm{std}}}{m_{\mathrm{sam}} \times\left(\frac{R_{\mathrm{spk}}}{R_{\mathrm{sam}}}-1\right)} .
$$

In Eq. (10), the values of $m_{1}, m_{2}$, and ${ }^{\mathrm{x}} c_{\text {std }}$ could be obtained from the records for the sample pretreatment, while $R_{\mathrm{spk}}$ and $R_{\mathrm{sam}}$ could be obtained from the signal intensities for elements $\mathrm{x}$ and $\mathrm{y}$ in the spiked sample and the non-spiked sample, respectively, measured by ICP-MS. Therefore, all of the parameters on the right side of Eq. (10) are known, so that the value of ${ }^{x} c_{\text {sam }}$ could be calculated. It is notable that the concentration of element $y$ (the internal standard), i.e., ${ }^{\mathrm{y}} C_{\text {sam }}$ is not included on the right side of Eq. (10), which means that an element with its concentration unknown could be used as the internal standard.

The concentration of element $x$ in a sample solution could be obtained with Eq. (10). In order to calculate the concentration of element $x$ in an initial sample, supposing that the sample solution was obtained by dilution of a digested solution of a solid sample, more parameters should be considered. For this purpose, Eq. (11) could be regarded as being a typical equation covering more parameters:

$$
{ }^{\mathrm{x}} C_{\mathrm{sld}}=\frac{m_{\mathrm{sln}} \times m_{\mathrm{dln}} \times m_{\mathrm{std}} \times{ }^{\mathrm{x}} C_{\mathrm{std}}}{m_{\mathrm{sld}} \times D \times m_{\mathrm{tkn}} \times m_{\mathrm{sam}} \times\left(\frac{R_{\mathrm{spk}} \div d}{R_{\mathrm{sam}}}-1\right)} \times r-B .
$$

In Eq. (11), $m_{\text {sld }}(\mathrm{g})$ of the solid sample was digested to obtain $m_{\mathrm{s} n}(\mathrm{~g})$ of the digested sample solution, $m_{\mathrm{tkn}}(\mathrm{g})$ of the digested solution sample was taken to obtain $m_{\mathrm{dnn}}(\mathrm{g})$ of the diluted sample solution and $m_{\text {sam }}(\mathrm{g})$ of the diluted sample was mixed with $m_{\text {std }}(\mathrm{g})$ of standard solution to obtain a spiked sample for SAM analysis. The parameters $D, d, r, B$ were for a dry mass correction, instrumental signal drift, reproducibility of the experiment, and procedure blank, respectively. It is notable that the $d$ parameter was applied only to $R_{\mathrm{spk}}$, but not to $R_{\mathrm{smp}}$ in Eq. (11), because the $d$ parameter was a relative value obtained by a measurement of the spiked sample bracketed by two measurements of the non-spiked sample, i.e. the $d$ parameter for $R_{\text {smp }}$ is 1.0 .

When the procedure blank was well controlled, the contribution of the $B$ parameter in Eq. (11) might be negligible. However, when the procedure blank was relatively higher (for example approximately $5 \%$ of the concentration in the sample) and its uncertainty contributed significantly to the analytical result, the uncertainty of the blank should be evaluated regarding the matrix effect on the sensitivity. ${ }^{42}$ For this purpose, the $B$ parameter could be calculated based on

$$
B=B_{0} \times \frac{\Delta^{\mathrm{x}} S_{\text {spk-sam }} / \Delta^{\mathrm{x}} c_{\text {spk-sam }}}{\Delta^{\mathrm{x}} S_{\text {spk-blk }} / \Delta^{\mathrm{x}} c_{\text {spk-blk }}}
$$


In Eq. (12), the parameter $B_{0}$ is the blank value without considering the matrix effect. The parameters $\Delta^{\mathrm{x}} S_{\text {spk-sam }}$ and $\Delta^{\mathrm{x}} S_{\text {spk-blk }}$ are the net signal intensities of element $\mathrm{x}$ in the spiked sample and the spiked blank, respectively. The parameters $\Delta^{\mathrm{x}} C_{\text {spk-sam }}$ and $\Delta^{\mathrm{x}} C_{\text {spk-blk }}$ are the spiked concentrations of element $\mathrm{x}$ in the spiked-sample and the spiked-blank, respectively, where the spiked-blank solution was obtained by the addition of the standard solution of element $\mathrm{x}$ into a blank solution.

\section{Experimental}

\section{Instruments}

All of the experiments in the present work were carried out based on Agilent 7700x or Agilent 8800s type ICP-MS instruments (Agilent Technologies Inc. Japan, Tokyo, Japan). The operating conditions of each instruments were daily optimized to achieve relatively high signal intensities for the elements of interest. When the elemental concentrations in a sample was relatively higher, the operating conditions were adjusted to obtain the signal intensity in an optimum linearity range, typically 10000 to 300000 CPS for both elements $\mathrm{x}$ and $\mathrm{y}$ in both the non-spiked sample and the spiked sample. Examples of typical operating conditions of the ICP-MS could be found in published works by the present authors. ${ }^{42,62}$ ETHOS 1 type and UltraWAVE type microwave digestion instruments (Milestone General K. K., Japan) were applied to the acid digestion of solid samples based on the established procedure with mix acid of $\mathrm{HNO}_{3}$ and $\mathrm{H}_{2} \mathrm{O}_{2} \cdot{ }^{47,64}$

\section{Chemicals}

Single-element standard solutions were purchased from Kanto Chemical Co., Inc. (Tokyo, Japan) to prepare the calibration standards for each element. All of the standard solutions were guaranteed by the Japan Calibration Service System (JCSS). Ultrapur $^{\circledR} \mathrm{HNO}_{3}, \mathrm{H}_{2} \mathrm{O}_{2}, \mathrm{HClO}_{4}$, and $\mathrm{HF}$ were also purchased from Kanto Chemical Co., Inc. and used for the digestion of the samples and for making measuring solutions.

\section{Dry-mass correction factor}

All of the certified values and the information values for the elements in solid samples were given on a dry-mass basis. The dry-mass correction parameter was obtained by drying the samples following the procedure given by the certificate of each certified reference material (CRM). Multiple sub-samples were prepared to assess the dry-mass correction parameter, which was in parallel to the microwave acid digestion of each solid sample.

\section{Results and Discussion}

In the present work, attention was paid to the accuracy of the measurement instead of the sensitivity, supposing that the elemental concentrations in a sample were high enough for precise measurements (relative standard deviation around or lower than $1.0 \%$ ) by ICP-MS. At the same time, all of the sample pretreatments were carried out based on gravimetric methods, ensuring that good linearity of the calibration curve could be obtained with a correlation factor $\left(R^{2}>0.9999\right)$.

\section{Principles for the selection of internal standard}

In the present work, the calibration was carried out by standard addition, i.e. the matrix of the calibration standard was identical to that of the sample so that the matrix effect in the measurement by ICP-MS could be cancelled. The internal standard element was measured for correcting any minute signal drift in the measurement by ICP-MS.

In a practical work, the element of interest (i.e. element $\mathrm{x}$ in the equations) might be regulated heavy metals, micro nutrients, and so on. In the present work, all of the elements with certified values in each CRM sample were measured as the elements of interest.

On the other hand, the internal standard element (i.e. element $y$ in the equations) could be selected based on the following considerations: free of spectral interference, without any apparent memory effect, with a proper concentration to provide a moderate signal intensity (typically 10000 CPS to 300000 CPS, considering the counting uncertainty and the linearity range of the detector of commercial ICP-MS) for a measurement with good precision (for example, relative standard deviation around or lower than $1.0 \%$ ). From the viewpoint of the measurement precision by ICP-MS, the signal intensity was considered for selecting the internal standard instead of the absolute concentration. This means that an element with relatively higher concentration could be used as the internal standard if it had an isotope with a relatively lower isotopic abundance, for example ${ }^{25} \mathrm{Mg}$ (approximately 10\%). The selection of the internal standard for the measurement by standard addition ICP-MS had been shown to be independent to the mass-to-charge ratio. ${ }^{47}$

\section{Dependence of relative standard deviation of the parameter for} the elemental signal intensity ratio on the relative concentration of the standard in the spiked sample

As can be seen from Eqs. (10) and (11), the only parameter obtained from the measurement by ICP-MS was $\left(R_{\mathrm{spk}} / R_{\mathrm{sam}}-1\right)$. Therefore, good control of the uncertainty for measuring $\left(R_{\mathrm{spk}} / R_{\mathrm{sam}}-1\right)$ contributed to an improvement of the precision of the analytical result. When the concentrations of the internal standard and that of the element of interest were high enough for a measurement, a good measurement precision by ICP-MS could be obtained for the parameters $R_{\text {spk }}$ and $R_{\text {sam }}$, respectively. As a result, the uncertainty for $\left(R_{\mathrm{spk}} / R_{\mathrm{sam}}-1\right)$ depended on the ratio of $R_{\mathrm{spk}} / R_{\mathrm{sam}}$, i.e. the relative concentration of the standard added to make the spiked sample.

The dependence of the relative standard deviation for $\left(R_{\mathrm{spk}} / R_{\mathrm{sam}}-1\right)$ on the ratio of $R_{\mathrm{spk}} / R_{\mathrm{sam}}$ is plotted in Fig. 1 , supposing that the relative standard deviations for $R_{\mathrm{spk}}$ and $R_{\mathrm{sam}}$ were $0.5 \%$. It can be seen from Fig. 1 that the relative standard deviation for $\left(R_{\mathrm{spk}} / R_{\mathrm{sam}}-1\right)$ was apparently higher, given a value generally over $1.0 \%$, when the ratio of $R_{\mathrm{spk}} / R_{\mathrm{sam}}$ was under 2.0 . When the ratio of $R_{\mathrm{spk}} / R_{\mathrm{sam}}$ was over 2.0, the relative standard deviation for $\left(R_{\text {spk }} / R_{\text {sam }}-1\right)$ decreased gradually and slightly with an increase of the ratio of $R_{\mathrm{spk}} / R_{\mathrm{sam}}$. However, the extent of decrease of the relative standard deviation for $\left(R_{\mathrm{spk}} / R_{\mathrm{sam}}-1\right)$ was negligible when the ratio of $R_{\mathrm{spk}} / R_{\mathrm{sam}}$ was over 3.0. Therefore, the standard added to make the spiked sample providing a ratio of $R_{\text {spk }} / R_{\text {sam }}$ in the range of 2.0 to 3.0 will provide a lower uncertainty for the measurement of $\left(R_{\mathrm{spk}} / R_{\mathrm{sam}}-1\right)$.

Dependence of the relatively signal intensities on the concentration of the matrix and the operating conditions

In order to elucidate the matrix effects in the measurement by ICP-MS, test solutions for $\mathrm{Cd}, \mathrm{Fe}$, and $\mathrm{Pb}$ with different matrix were prepared and measured by an ICP-MS instrument. The concentrations of each elements in each test solution were $10 \mathrm{ng} \mathrm{g}^{-1}$, so as to obtain sufficient signal intensities for a comparison. Four sets test solutions (blank and standard) having different matrix were investigated for comparing the 
matrix effects, i.e. $0.3 \mathrm{~mol} \mathrm{~L}^{-1}$ of $\mathrm{HNO}_{3}, 2.0 \mathrm{~mol} \mathrm{~L}-1$ of $\mathrm{HNO}_{3}$, $100 \mu \mathrm{g} \mathrm{g}^{-1}$ of $\mathrm{Na}$ in $0.3 \mathrm{~mol} \mathrm{~L}^{-1}$ of $\mathrm{HNO}_{3}$, and $100 \mu \mathrm{g} \mathrm{g}^{-1}$ of $\mathrm{K}$ in $0.3 \mathrm{~mol} \mathrm{~L}^{-1}$ of $\mathrm{HNO}_{3}$. The elements $(\mathrm{Fe}, \mathrm{Cd}$, and $\mathrm{Pb})$ were selected to cover a wide range of mass-to-charge ratio, while $\mathrm{Na}$ and $\mathrm{K}$ were the typical matrix elements in geological samples and plant samples.

The results are plotted in Figs. 2(a) and 2(b), obtained under low and high sensitivity conditions, respectively. The results given in Fig. 2 are shown as the relative signal intensities compared to those in the standard solution with $0.3 \mathrm{~mol} \mathrm{~L}^{-1}$ of $\mathrm{HNO}_{3}$. It can be seen from Fig. 2(a) that the relative signal intensities might decreased down to approximately $-10 \%$ for $\mathrm{Fe}$ in $100 \mu \mathrm{g} \mathrm{g}^{-1}$ of $\mathrm{K}$. In contrast, the relative signal intensities in Fig. 2(b) for $\mathrm{Pb}$ and $\mathrm{Fe}$ in $100 \mu \mathrm{g} \mathrm{g}^{-1}$ of $\mathrm{K}$ increased up to approximately $+15 \%$. Such variations of the relative signal intensities indicate that the accuracy of the measurement could have been deteriorated due to the matrix effect in the analysis by ICP-MS. Therefore, approaches for the removal or cancelling of matrix effects are required for accurate measurements by ICP-MS

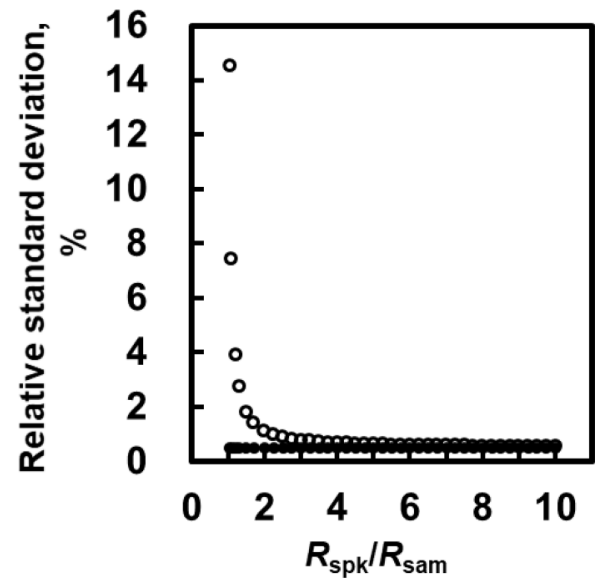

Fig. 1 Dependence of the relative standard deviation of the parameter for the elemental signal intensity ratio on the relative concentration of the standard in the spiked sample. $\bigcirc,\left(R_{\mathrm{spk}} / R_{\mathrm{sam}}-1\right)$; , $R_{\mathrm{spk}}$ and $R_{\mathrm{sam}}$.
An example of elemental signal intensities and the calculation for Fe in NMIJ CRM 7512-a (milk powder)

For a better understanding of the present method, the procedure for the determination of Fe in NMIJ CRM 7512-a is explained in this section.

The data obtained by ICP-MS are summarized in Table 2. In Table 2, the isotopes ${ }^{25} \mathrm{Mg}$ and ${ }^{56} \mathrm{Fe}$ were measured as the internal standard and the target isotope, respectively. Five repetitions (Rep01 to Rep05) were obtained for both isotopes in each measurement. After the measurement of the "Blank" sample, two measurements of the "Non-spiked" sample bracketing a measurement of the "Spiked" sample were performed. The data for the "Signal Intensity" were obtained from the measurement by the ICP-MS. The values of "Mean" and " $u$ " could be calculated from the data of five repetitions in each measurement, while " $u$ " is the standard uncertainty which is calculated by dividing the standard deviation with the square root of the repetition number. The data for the "Signal Intensity Ratio" (i.e. $R_{\text {sam }}$ and $R_{\text {spk }}$ ) were obtained as the ratio of the net signal intensities, i.e. after subtracting the "Mean" values (13 CPS and 279 CPS for ${ }^{25} \mathrm{Mg}$ and ${ }^{56} \mathrm{Fe}$, respectively) in the "Blank" sample. The "Signal Intensity Ratio" could be obtained

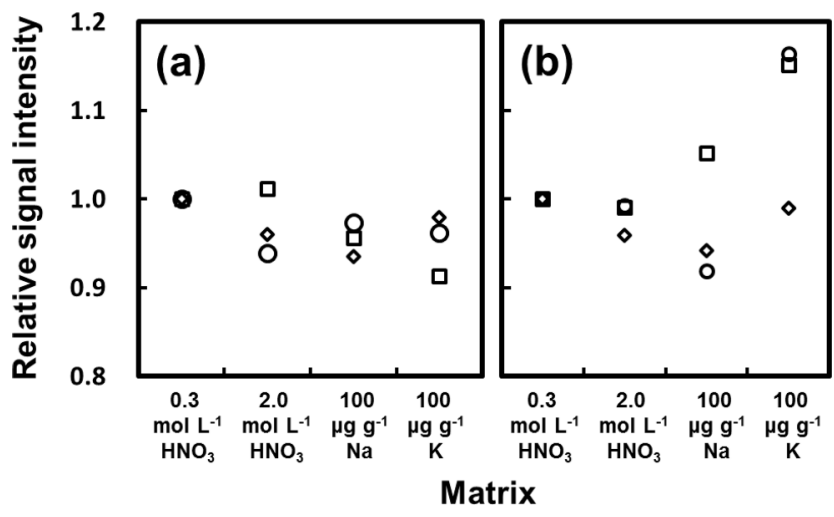

Fig. 2 Dependence of the relative signal intensities of the elements on the matrix. $\square, \mathrm{Fe} ; \diamond, \mathrm{Cd}, \bigcirc, \mathrm{Pb}$. (a) Operated at low sensitivity mode, $1.0 \times 10^{4} \mathrm{cps} \cdot \mathrm{g} \mathrm{ng}^{-1}$ for ${ }^{89} \mathrm{Y}^{+}$. (b) Operated at the high-sensitivity mode, $1.0 \times 10^{5} \mathrm{cps} \cdot \mathrm{g} \mathrm{ng}^{-1}$ for ${ }^{89} \mathrm{Y}^{+}$

Table 2 An example of the measurement and the calculation

\begin{tabular}{|c|c|c|c|c|c|c|c|c|c|c|}
\hline \multirow{2}{*}{ Element } & \multirow{2}{*}{ Sample } & \multicolumn{5}{|c|}{ Signal intensity/CPS } & \multirow{2}{*}{$\begin{array}{c}\text { Mean/ } \\
\text { CPS }\end{array}$} & \multirow{2}{*}{$u / \mathrm{CPS}$} & \multirow{2}{*}{$u, \%$} & \\
\hline & & Rep01 & Rep02 & Rep03 & Rep04 & Rep05 & & & & \\
\hline \multirow[t]{4}{*}{${ }^{25} \mathrm{Mg}$} & Blank & 7 & 18 & 15 & 14 & 12 & 13 & 2 & 13.5 & \\
\hline & Non-spiked-1 & 31291 & 31184 & 31133 & 31001 & 31407 & 31203 & 69 & 0.22 & \\
\hline & Spiked & 28893 & 28729 & 28770 & 28943 & 28566 & 28780 & 66 & 0.23 & \\
\hline & Non-spiked-2 & 32041 & 32161 & 32038 & 31916 & 32209 & 32073 & 52 & 0.16 & \\
\hline \multirow[t]{4}{*}{${ }^{56} \mathrm{Fe}$} & Blank & 274 & 262 & 291 & 280 & 288 & 279 & 5 & 1.88 & \\
\hline & Non-spiked-1 & 149264 & 147641 & 148185 & 147956 & 149194 & 148448 & 331 & 0.22 & \\
\hline & Spiked & 267532 & 265787 & 268066 & 267912 & 265037 & 266867 & 612 & 0.23 & \\
\hline & Non-spiked-2 & 152782 & 154410 & 153557 & 152525 & 153624 & 153380 & 335 & 0.22 & \\
\hline \multirow{2}{*}{$\begin{array}{l}\text { Element } \\
\text { pair }\end{array}$} & \multirow{2}{*}{ Sample } & \multicolumn{5}{|c|}{ Signal intensity ratio } & \multirow{2}{*}{ Mean } & \multirow{2}{*}{$u$} & \multirow{2}{*}{$u, \%$} & \multirow{2}{*}{$d$} \\
\hline & & Rep01 & Rep02 & Rep03 & Rep04 & Rep05 & & & & \\
\hline \multirow[t]{3}{*}{${ }^{56} \mathrm{Fe} /{ }^{25} \mathrm{Mg}$} & Non-spiked-1 & 4.763 & 4.728 & 4.753 & 4.766 & 4.743 & 4.751 & 0.007 & 0.15 & 1.000 \\
\hline & Spiked & 9.254 & 9.246 & 9.312 & 9.251 & 9.272 & 9.267 & 0.012 & 0.13 & 1.003 \\
\hline & Non-spiked-2 & 4.762 & 4.794 & 4.786 & 4.772 & 4.763 & 4.775 & 0.006 & 0.14 & 1.005 \\
\hline
\end{tabular}


Table 3 Parameters for calculating the mean value for the concentration of $\mathrm{Fe}$ in NMIJ CRM 7512-a

\begin{tabular}{lrrrc}
\hline Parameter & Sample-1 & Sample-2 & Sample-3 & Unit \\
\hline$m_{\text {sld }}$ & 0.5274 & 0.5009 & 0.5197 & $\mathrm{~g}$ \\
$m_{\text {sol }}$ & 50.8445 & 50.2761 & 50.3782 & $\mathrm{~g}$ \\
$D$ & 0.9749 & 0.9764 & 0.9632 & - \\
$r$ & 1.0000 & 1.0000 & 1.0000 & - \\
$m_{\text {tkn }}$ & 0.9937 & 0.9961 & 0.9928 & $\mathrm{~g}$ \\
$m_{\text {dln }}$ & 50.0092 & 50.0116 & 50.2729 & $\mathrm{~g}$ \\
$d$ & 1.0026 & 1.0000 & 1.0000 & - \\
${ }^{\mathrm{x}} c_{\text {std }}$ & 0.1958 & 0.1958 & 0.1958 & $\mu \mathrm{g} \mathrm{g}^{-1}$ \\
$m_{\text {sam }}$ & 10.0585 & 10.0547 & 10.0852 & $\mathrm{~g}$ \\
$m_{\text {std }}$ & 0.9910 & 0.9923 & 0.9924 & $\mathrm{~g}$ \\
$R_{\text {sam }}$ & 4.7505 & 4.8267 & 4.8406 & - \\
$R_{\text {spk }}$ & 9.2671 & 9.6114 & 9.5831 & - \\
$B$ & 0 & 0 & 0 & $\mu \mathrm{g} \mathrm{g}^{-1}$ \\
${ }^{\mathrm{x}} c_{\text {sld }}$ & 101.2 & 100.6 & 100.2 & $\mu \mathrm{g} \mathrm{g}^{-1}$ \\
Mean & 100.7 & & & $\mu \mathrm{g} \mathrm{g}^{-1}$ \\
$u$ & 0.3 & & & $\mu \mathrm{g} \mathrm{g}^{-1}$ \\
$u_{\text {Relative }} u$ & 0.30 & & & $\%$ \\
\hline
\end{tabular}

for each repetition in a measurement. It is notable that the values for the "Relative $u$ " of the "Signal Intensity Ratio" were apparently lower than those of the "Signal Intensity", indicating that the internal standard correction was effective for cancelling the transient signal variation in each measurement. The mean values of the "Signal Intensity Ratio" for "Non-spiked-1" and "Spiked" sample (4.751 and 9.267, respectively) along with the correction factors for signal drift " $d$ " were used in the following text for calculating the concentration of $\mathrm{Fe}$ in the sample. The value of $d$ was calculated while considering the relative signal intensity drift observed "Non-spiked-2" compared to the signal intensity observed in "Non-spiked-1".

Representative data for calculating the concentration of $\mathrm{Fe}$ in NMIJ CRM 7512-a (milk powder) by SAM ICP-MS

The data for calculating the concentration of $\mathrm{Fe}$ in NMIJ CRM 7512-a are summarized in Table 3, where three independent subsamples (Samples-1 to -3 from different bottles of CRM) were digested, diluted, and analyzed, respectively. As can be seen in Table 3, approximately $0.5 \mathrm{~g}$ of the sample was digested to obtain approximately $50 \mathrm{~g}$ of the sample solution. Approximately $1.0 \mathrm{~g}$ of the digested sample solution was taken and transferred to approximately $50 \mathrm{~g}$ of a diluted sample solution for analysis. The spiked-sample for SAM analysis was obtained by mixing approximately $10 \mathrm{~g}$ of the diluted sample solution with approximately $1.0 \mathrm{~g}$ of the standard solution. The dry mass correction factor $(D)$ for each sub-sample was obtained following the instruction of the certificate of the CRM. The procedure blank $(B)$ was obtained by carrying out blank digestions paralleled with the samples; the value was less than $10^{-5}$ times the concentration in the sample, and given as " 0 " in Table 3. The values of $R_{\mathrm{sam}}$ and $R_{\mathrm{spk}}$ were obtained in the same way as given in Table 2. The relative $u(0.30 \%)$ of the values of ${ }^{\mathrm{x}} c_{\text {sld }}$ obtained in Table 3 was considered to be the uncertainty of reproducibility of the experiment $(r)$.

Calculation of combined uncertainty for the concentration of $\mathrm{Fe}$ in NMIJ CRM 7512-a obtained with the present method

The combined uncertainty for the results obtained by the present method could be calculated by taking into consideration the contribution of each parameter in Eq. (11). The typical value and its standard uncertainty of each parameter for
Table 4 Uncertainty calculation for the concentration of $\mathrm{Fe}$ in NMIJ CRM 7512-a

\begin{tabular}{lccccc}
\hline Parameter & $\begin{array}{c}\text { Typical } \\
\text { value }\end{array}$ & $\begin{array}{c}\text { Standard } \\
\text { uncertainty }\end{array}$ & Unit & $\begin{array}{c}\text { Contribution, } \\
\%\end{array}$ & $\begin{array}{c}\text { Type of } \\
\text { uncertainty }\end{array}$ \\
\hline$m_{\text {sld }}$ & 0.5274 & 0.0002 & $\mathrm{~g}$ & 0.5 & $\mathrm{~B}$ \\
$m_{\text {sol }}$ & 50.8445 & 0.0002 & $\mathrm{~g}$ & $<0.1$ & $\mathrm{~B}$ \\
$D$ & 0.9749 & 0.0002 & - & 0.2 & $\mathrm{~A}$ \\
$r$ & 1.0000 & 0.0030 & - & 28.1 & $\mathrm{~A}$ \\
$m_{\text {tkn }}$ & 0.9937 & 0.0002 & $\mathrm{~g}$ & 0.1 & $\mathrm{~B}$ \\
$m_{\mathrm{dln}}$ & 50.0092 & 0.0002 & $\mathrm{~g}$ & $<0.1$ & $\mathrm{~B}$ \\
$d$ & 1.0026 & 0.0014 & - & 6.3 & $\mathrm{~A}$ \\
${ }^{\mathrm{x}} c_{\text {std }}$ & 0.1958 & 0.0004 & $\mu \mathrm{g} \mathrm{g}^{-1}$ & 12.8 & $\mathrm{~B}$ \\
$m_{\text {sam }}$ & 10.0585 & 0.0002 & $\mathrm{~g}$ & $<0.1$ & $\mathrm{~B}$ \\
$m_{\text {std }}$ & 0.9910 & 0.0002 & $\mathrm{~g}$ & 0.1 & $\mathrm{~B}$ \\
$R_{\text {sam }}$ & 4.7505 & 0.0070 & - & 29.1 & $\mathrm{~A}$ \\
$R_{\text {spk }}$ & 9.2671 & 0.0121 & - & 22.8 & $\mathrm{~A}$ \\
$B$ & 0 & 0 & $\mu \mathrm{g} \mathrm{g}^{-1}$ & 0 & $\mathrm{~A}$ \\
${ }^{\mathrm{x}} c_{\text {sld }}$ & 101.2 & & $\mu \mathrm{g} \mathrm{g}^{-1}$ & & \\
$u_{\mathrm{c}}$ & 0.57 & & $\mu \mathrm{g} \mathrm{g}^{-1}$ & & \\
Relative $u_{\mathrm{c}}$ & 0.56 & & $\%$ & & \\
\hline
\end{tabular}

Table 5 Reported values for the elemental concentrations obtained by the present method in comparison to reference values of international comparisons ${ }^{66-70}$

\begin{tabular}{|c|c|c|c|}
\hline \multirow{2}{*}{ Element $^{\mathrm{a}}$} & Reported value & Reference value & \multirow{2}{*}{ Unit } \\
\hline & Mean $\pm U$ & Meal & \\
\hline \multicolumn{4}{|c|}{ CCQM-K100: Analysis of copper in ethanol } \\
\hline${ }^{63} \mathrm{Cu}\left({ }^{59} \mathrm{Co}\right)$ & $0.3583 \pm 0.0044$ & $0.3589 \pm 0.0028$ & $\mu \mathrm{g} \mathrm{g}^{-1}$ \\
\hline \multicolumn{4}{|c|}{ CCQM-K107: Total elements and selenomethionine in human serur } \\
\hline${ }^{56} \mathrm{Fe}\left({ }^{85} \mathrm{Rb}\right)$ & $531 \pm 11$ & $515.63 \pm 21.95$ & $\mu \mathrm{g} \mathrm{g}^{-1}$ \\
\hline${ }^{39} \mathrm{~K}\left({ }^{137} \mathrm{Ba}\right)$ & $141.2 \pm 1.5$ & $141.20 \pm 1.14$ & $\mu \mathrm{g} \mathrm{g}^{-1}$ \\
\hline${ }^{24} \mathrm{Mg}\left({ }^{137} \mathrm{Ba}\right)$ & $21.0 \pm 0.4$ & $20.39 \pm 0.26$ & $\mu \mathrm{g} \mathrm{g}^{-1}$ \\
\hline${ }^{40} \mathrm{Ca}\left({ }^{85} \mathrm{Rb}\right)$ & $86.3 \pm 1.3$ & $87.02 \pm 0.26$ & $\mu \mathrm{g} \mathrm{g}^{-1}$ \\
\hline \multicolumn{4}{|c|}{$\begin{array}{l}\text { CCQM-K124: Trace elements and chromium speciation in } \\
\text { drinking water }\end{array}$} \\
\hline${ }^{75} \mathrm{As}\left({ }^{85} \mathrm{Rb}\right)$ & $5.33 \pm 0.14$ & $5.346 \pm 0.025$ & $\mu \mathrm{g} \mathrm{g}^{-1}$ \\
\hline \multicolumn{4}{|c|}{ CCQM-K125: Elements in infant formula } \\
\hline${ }^{127} \mathrm{I}\left({ }^{85} \mathrm{Rb}\right)$ & $1.30 \pm 0.02$ & $1.314 \pm 0.036$ & $\mu \mathrm{g} \mathrm{g}^{-1}$ \\
\hline \multicolumn{4}{|c|}{ APMP.QM-S5: Essential and toxic elements in seafood } \\
\hline${ }^{75} \mathrm{As}\left({ }^{63} \mathrm{Cu}\right)$ & $44.7 \pm 0.9$ & $44.7 \pm 1.2$ & $\mu \mathrm{g} \mathrm{g}^{-1}$ \\
\hline${ }^{110} \mathrm{Cd}\left({ }^{89} \mathrm{Y}\right)$ & $0.223 \pm 0.004$ & $0.224 \pm 0.011$ & $\mu g \mathrm{~g}^{-1}$ \\
\hline${ }^{56} \mathrm{Fe}\left({ }^{88} \mathrm{Sr}\right)$ & $183.5 \pm 3.5$ & $183.5 \pm 4.3$ & $\mu \mathrm{g} \mathrm{g}^{-1}$ \\
\hline${ }^{66} \mathrm{Zn}\left({ }^{63} \mathrm{Cu}\right)$ & $59.5 \pm 1.5$ & $60.0 \pm 1.1$ & $\mu \mathrm{g} \mathrm{g}^{-1}$ \\
\hline
\end{tabular}

a. An element in the brackets is the internal standard element.

calculating the combined uncertainty of the Fe concentration in NMIJ CRM 7512-a are summarized in Table 4. Following the instruction of JCGM100:2008, ${ }^{65}$ the sources of the standard uncertainty could be classified into two types, Type A and Type B, respectively. All of the parameters of Type A in Table 4 were calculated from data obtained in the present experiment, while those of Type B were obtained from reference information from JCSS.

The standard uncertainty for each parameter of Type A was calculated by dividing the standard deviation of the mean value with the square root of repetition number $(n)$. The combined uncertainty $\left(u_{\mathrm{c}}\right)$ could be calculated with a spreadsheet approach based on Eq. (11), while taking into consideration the typical value and the standard uncertainty of each parameter. It can be seen from Table 4 that the values of $u_{\mathrm{c}}$ and the relative $u_{\mathrm{c}}$ were 
Table 6(a) Uncertainty calculation for the concentrations of As and Cd in a seafood sample

\begin{tabular}{|c|c|c|c|c|c|c|c|c|}
\hline \multirow{2}{*}{ Parameter } & \multicolumn{4}{|c|}{ As } & \multicolumn{4}{|c|}{$\mathrm{Cd}$} \\
\hline & $\begin{array}{l}\text { Typical } \\
\text { value }\end{array}$ & $\begin{array}{l}\text { Standard } \\
\text { uncertainty }\end{array}$ & Unit & $\begin{array}{c}\text { Contribution, } \\
\%\end{array}$ & $\begin{array}{l}\text { Typical } \\
\text { value }\end{array}$ & $\begin{array}{l}\text { Standard } \\
\text { uncertainty }\end{array}$ & Unit & $\begin{array}{c}\text { Contribution, } \\
\%\end{array}$ \\
\hline$m_{\text {sld }}$ & 0.2998 & 0.0002 & $\mathrm{~g}$ & 0.4 & 0.2990 & 0.0002 & $\mathrm{~g}$ & 0.7 \\
\hline$m_{\text {sol }}$ & 31.8324 & 0.0002 & $\mathrm{~g}$ & $<0.1$ & 33.8286 & 0.0002 & $\mathrm{~g}$ & $<0.1$ \\
\hline$D$ & 0.8513 & 0.0005 & - & 0.4 & 0.8513 & 0.0005 & - & 0.6 \\
\hline$r$ & 1.0000 & 0.0077 & - & 58.0 & 1.0000 & 0.0008 & - & 0.8 \\
\hline$m_{\mathrm{tkn}}$ & 0.4962 & 0.0002 & $\mathrm{~g}$ & 0.2 & $1.0000^{\mathrm{a}}$ & 0.0000 & $\mathrm{~g}$ & 0 \\
\hline$m_{\mathrm{dln}}$ & 50.6388 & 0.0002 & $\mathrm{~g}$ & $<0.1$ & $1.0000^{\mathrm{a}}$ & 0.0000 & $\mathrm{~g}$ & 0 \\
\hline$d$ & 1.0000 & 0.0010 & - & 0.9 & 1.0000 & 0.0031 & - & 14.3 \\
\hline${ }^{\mathrm{x}} C_{\text {std }}$ & 0.0656 & 0.0002 & $\mu \mathrm{g} \mathrm{g}^{-1}$ & 11.9 & 0.0842 & 0.0003 & $\mu \mathrm{g} \mathrm{g}^{-1}$ & 18.2 \\
\hline$m_{\text {sam }}$ & 9.3547 & 0.0002 & $\mathrm{~g}$ & $<0.1$ & 9.2352 & 0.0002 & $\mathrm{~g}$ & $<0.1$ \\
\hline$m_{\text {std }}$ & 0.4933 & 0.0002 & $\mathrm{~g}$ & 0.1 & 0.4940 & 0.0002 & $\mathrm{~g}$ & 0.2 \\
\hline$R_{\text {sam }}$ & 0.4811 & 0.0009 & - & 12.8 & 0.5707 & 0.0025 & - & 53.0 \\
\hline$R_{\mathrm{spk}}$ & 0.9561 & 0.0020 & - & 15.3 & 2.1035 & 0.0045 & - & 12.1 \\
\hline$B$ & 0.0008 & 0.0002 & $\mu \mathrm{g} \mathrm{g}^{-1}$ & $<0.1$ & 0.0000 & 0.0000 & $\mu \mathrm{g} \mathrm{g}^{-1}$ & $<0.1$ \\
\hline${ }^{\mathrm{x}} C_{\text {sam }}$ & 44.58 & & $\mu \mathrm{g} \mathrm{g}^{-1}$ & & 0.2229 & & $\mu \mathrm{g} \mathrm{g}^{-1}$ & \\
\hline$u_{\mathrm{c}}$ & 0.45 & & $\mu \mathrm{g} \mathrm{g}^{-1}$ & & 0.0002 & & $\mu \mathrm{g} \mathrm{g}^{-1}$ & \\
\hline Relative $u_{\mathrm{c}}$ & 1.01 & & $\%$ & & 0.82 & & $\%$ & \\
\hline
\end{tabular}

a. Dilution was not carried out for the digested sample solution $\left(m_{\mathrm{tkn}}=m_{\mathrm{dn} n}\right)$.

Table 6(b) Uncertainty calculation for the concentrations of Fe and $\mathrm{Zn}$ in a seafood sample

\begin{tabular}{|c|c|c|c|c|c|c|c|c|}
\hline \multirow{2}{*}{ Parameter } & \multicolumn{4}{|c|}{$\mathrm{Fe}$} & \multicolumn{4}{|c|}{$\mathrm{Zn}$} \\
\hline & $\begin{array}{l}\text { Typical } \\
\text { value }\end{array}$ & $\begin{array}{c}\text { Standard } \\
\text { uncertainty }\end{array}$ & Unit & $\begin{array}{c}\text { Contribution, } \\
\%\end{array}$ & $\begin{array}{l}\text { Typical } \\
\text { value }\end{array}$ & $\begin{array}{c}\text { Standard } \\
\text { uncertainty }\end{array}$ & Unit & $\begin{array}{c}\text { Contribution, } \\
\%\end{array}$ \\
\hline$m_{\text {sld }}$ & 0.2990 & 0.0002 & g & 0.5 & 0.2998 & 0.0002 & g & 0.3 \\
\hline$m_{\text {sol }}$ & 33.8286 & 0.0002 & $\mathrm{~g}$ & $<0.1$ & 31.8324 & 0.0002 & $\mathrm{~g}$ & $<0.1$ \\
\hline$D$ & 0.8513 & 0.0013 & - & 2.7 & 0.8513 & 0.0005 & - & 0.3 \\
\hline$r$ & 1.0000 & 0.0076 & - & 61.9 & 1.0000 & 0.0099 & - & 60.7 \\
\hline$m_{\mathrm{tkn}}$ & 0.4937 & 0.0002 & $\mathrm{~g}$ & 0.2 & 0.4962 & 0.0002 & g & 0.1 \\
\hline$m_{\mathrm{dln}}$ & 50.8401 & 0.0002 & g & $<0.1$ & 50.6388 & 0.0002 & $\mathrm{~g}$ & $<0.1$ \\
\hline$d$ & 1.0000 & 0.0010 & - & 1.0 & 1.0000 & 0.0010 & - & 0.6 \\
\hline${ }^{\mathrm{x}} c_{\text {std }}$ & 0.2660 & 0.0009 & $\mu \mathrm{g} \mathrm{g}^{-1}$ & 13.1 & 0.0839 & 0.0003 & $\mu \mathrm{g} \mathrm{g}^{-1}$ & 7.6 \\
\hline$m_{\mathrm{sam}}$ & 9.0467 & 0.0002 & $\mathrm{~g}$ & $<0.1$ & 9.3547 & 0.0002 & $\mathrm{~g}$ & $<0.1$ \\
\hline$m_{\text {std }}$ & 0.4929 & 0.0002 & $\mathrm{~g}$ & 0.1 & 0.4933 & 0.0002 & $\mathrm{~g}$ & 0.1 \\
\hline$R_{\mathrm{sam}}$ & 2.9488 & 0.0053 & - & 11.9 & 0.9253 & 0.0020 & - & 11.2 \\
\hline$R_{\mathrm{spk}}$ & 6.1491 & 0.0096 & - & 8.7 & 1.8050 & 0.0052 & - & 19.2 \\
\hline$B$ & 0.0400 & 0.0002 & $\mu \mathrm{g} \mathrm{g}^{-1}$ & $<0.1$ & 0.0008 & 0.0007 & $\mu \mathrm{g} \mathrm{g}^{-1}$ & $<0.1$ \\
\hline${ }^{\mathrm{x}} c_{\text {sam }}$ & 182.7 & & $\mu \mathrm{g} \mathrm{g}^{-1}$ & & 59.21 & & $\mu \mathrm{g} \mathrm{g}^{-1}$ & \\
\hline$u_{\mathrm{c}}$ & 1.8 & & $\mu \mathrm{g} \mathrm{g}^{-1}$ & & 0.75 & & $\mu \mathrm{g} \mathrm{g}^{-1}$ & \\
\hline Relative $u_{\mathrm{c}}$ & 0.97 & & $\%$ & & 1.27 & & $\%$ & \\
\hline
\end{tabular}

$0.57 \mu \mathrm{g} \mathrm{g}^{-1}$ and $0.56 \%$, respectively. The expanded uncertainty $(U)$ of the measurement could be calculated by multiplication of the value of $u_{\mathrm{c}}$ with a coverage factor $(k)$ of 2 , giving a level of confidence of approximately $95 \%$.

As a result, the observed value for the concentration of $\mathrm{Fe}$ in NMIJ CRM 7512-a was $(100.7 \pm 1.1) \mu \mathrm{g} \mathrm{g}^{-1}$, which agreed with the certified value $(104 \pm 7) \mu \mathrm{g} \mathrm{g}^{-1}$, where both values are given as the (Mean $\pm U$ ).

It is notable that the major contributions to $u_{\mathrm{c}}$ were from of $r$ (28.1\%), $R_{\mathrm{sam}}(29.1 \%)$, and $R_{\mathrm{spk}}(22.8 \%)$, respectively. Therefore, further improvement of the precision for these parameters will help to obtain analytical results with lower uncertainty.

Application of the present method to various international comparisons in chemical metrology

The present method had been applied to international comparisons for chemical metrology, covering various matrix, such as bioethanol, human serum, biodiesel fuel, drinking water, infant formula milk power, and seafood. ${ }^{66-70}$

The reported results for the elemental concentrations obtained by the present method are summarized in Table 5 compared with reference values of the international comparisons. It can be seen from Table 5 that each reported value agrees with its corresponding reference value in the range of the expanded uncertainty, indicating that the present method was effective for measuring the elements in various matrix.

It can be seen in Table 5 that the concentrations of $\mathrm{As}, \mathrm{Cd}, \mathrm{Fe}$, and $\mathrm{Zn}$ in the sample of APMP.QM-S5 (seafood) covered a wide range from $0.223 \mu \mathrm{g} \mathrm{g}^{-1}$ of $\mathrm{Cd}$ to $183.5 \mu \mathrm{g} \mathrm{g}^{-1}$ of Fe. In order to investigate the typical factors contributing to the uncertainty of the measurement, a comparison of the uncertainty calculation for the concentrations of these elements is summarized in Tables 6(a) and 6(b). It can be seen from Tables 6(a) and 6(b) that the major contributions to the uncertainty of $\mathrm{As}, \mathrm{Fe}$, and $\mathrm{Zn}$ were $r,{ }^{\mathrm{x}} c_{\mathrm{std}}, R_{\mathrm{sam}}$, and $R_{\mathrm{spk}}$, the values for all of which were close to or exceeded $10 \%$. In contrast, the major contributions to the 
Table 7 Analytical results of the elements in NMIJ CRM 7203-a (tap water)

\begin{tabular}{|c|c|c|c|}
\hline \multirow{2}{*}{ Element $^{\mathrm{a}}$} & Observed value & Certified value & \multirow{2}{*}{ Unit } \\
\hline & Mean $\pm U$ & Mean $\pm U$ & \\
\hline${ }^{40} \mathrm{Ca}\left({ }^{59} \mathrm{Co}\right)$ & $18.0 \pm 0.1$ & $18.1 \pm 0.6$ & $\mathrm{mg} \mathrm{kg}^{-1}$ \\
\hline${ }^{39} \mathrm{~K}\left({ }^{59} \mathrm{Co}\right)$ & $5.26 \pm 0.08$ & $5.35 \pm 0.16$ & $\mathrm{mg} \mathrm{kg}^{-1}$ \\
\hline${ }^{24} \mathrm{Mg}\left({ }^{59} \mathrm{Co}\right)$ & $7.7 \pm 0.1$ & $7.9 \pm 0.3$ & $\mathrm{mg} \mathrm{kg}^{-1}$ \\
\hline${ }^{23} \mathrm{Na}\left({ }^{59} \mathrm{Co}\right)$ & $33.4 \pm 0.52$ & $33.1 \pm 1.1$ & $\mathrm{mg} \mathrm{kg}^{-1}$ \\
\hline${ }^{27} \mathrm{Al}\left({ }^{25} \mathrm{Mg}\right)$ & $67.0 \pm 0.16$ & $67 \pm 3$ & $\mu \mathrm{g} \mathrm{kg}^{-1}$ \\
\hline${ }^{75} \mathrm{As}\left({ }^{84} \mathrm{Sr}\right)$ & $5.25 \pm 0.02$ & $5.3 \pm 0.3$ & $\mu \mathrm{g} \mathrm{kg}^{-1}$ \\
\hline${ }^{11} \mathrm{~B}\left({ }^{25} \mathrm{Mg}\right)$ & $43.2 \pm 0.27$ & $43 \pm 4$ & $\mu \mathrm{g} \mathrm{kg}^{-1}$ \\
\hline${ }^{110} \mathrm{Cd}\left({ }^{55} \mathrm{Mn}\right)$ & $0.353 \pm 0.006$ & $0.345 \pm 0.020$ & $\mu \mathrm{g} \mathrm{kg}^{-1}$ \\
\hline${ }^{52} \mathrm{Cr}\left({ }^{84} \mathrm{Sr}\right)$ & $5.06 \pm 0.06$ & $5.03 \pm 0.12$ & $\mu \mathrm{g} \mathrm{kg}^{-1}$ \\
\hline${ }^{65} \mathrm{Cu}\left({ }^{84} \mathrm{Sr}\right)$ & $9.01 \pm 0.03$ & $9.2 \pm 0.3$ & $\mu \mathrm{g} \mathrm{kg}^{-1}$ \\
\hline${ }^{56} \mathrm{Fe}\left({ }^{84} \mathrm{Sr}\right)$ & $7.70 \pm 0.18$ & $7.7 \pm 0.3$ & $\mu \mathrm{g} \mathrm{kg}^{-1}$ \\
\hline${ }^{55} \mathrm{Mn}\left({ }^{84} \mathrm{Sr}\right)$ & $5.09 \pm 0.02$ & $5.0 \pm 0.3$ & $\mu \mathrm{g} \mathrm{kg}^{-1}$ \\
\hline${ }^{98} \mathrm{Mo}\left({ }^{55} \mathrm{Mn}\right)$ & $1.02 \pm 0.02$ & $1.02 \pm 0.09$ & $\mu \mathrm{g} \mathrm{kg}^{-1}$ \\
\hline${ }^{60} \mathrm{Ni}\left({ }^{55} \mathrm{Mn}\right)$ & $0.70 \pm 0.04$ & $0.70 \pm 0.07$ & $\mu \mathrm{g} \mathrm{kg}^{-1}$ \\
\hline${ }^{208} \mathrm{~Pb}\left({ }^{55} \mathrm{Mn}\right)$ & $0.76 \pm 0.01$ & $0.77 \pm 0.04$ & $\mu \mathrm{g} \mathrm{kg}^{-1}$ \\
\hline${ }^{85} \mathrm{Rb}\left({ }^{84} \mathrm{Sr}\right)$ & $3.62 \pm 0.01$ & $3.65 \pm 0.11$ & $\mu \mathrm{g} \mathrm{kg}^{-1}$ \\
\hline${ }^{121} \mathrm{Sb}\left({ }^{55} \mathrm{Mn}\right)$ & $0.147 \pm 0.002$ & $0.146 \pm 0.009$ & $\mu \mathrm{g} \mathrm{kg}^{-1}$ \\
\hline${ }^{78} \mathrm{Se}\left({ }^{84} \mathrm{Sr}\right)$ & $5.02 \pm 0.05$ & $5.0 \pm 0.2$ & $\mu \mathrm{g} \mathrm{kg}^{-1}$ \\
\hline${ }^{88} \mathrm{Sr}\left({ }^{25} \mathrm{Mg}\right)$ & $107.6 \pm 0.77$ & $107 \pm 3$ & $\mu \mathrm{g} \mathrm{kg}^{-1}$ \\
\hline${ }^{66} \mathrm{Zn}\left({ }^{84} \mathrm{Sr}\right)$ & $11.5 \pm 0.2$ & $12.0 \pm 0.6$ & $\mu \mathrm{g} \mathrm{kg}^{-1}$ \\
\hline
\end{tabular}

a. An element in the brackets is the internal standard element.

uncertainty of Cd were $d,{ }^{\mathrm{x}} c_{\mathrm{std}}, R_{\mathrm{sam}}$, and $R_{\mathrm{spk}}$. These results might indicate that the homogeneity of $\mathrm{Cd}$ in the sample was better than those of $\mathrm{As}, \mathrm{Fe}$, and $\mathrm{Zn}$, resulting in a better reproducibility in the subsamples, i.e. a lower value of standard uncertainty for the $r$ parameter. On the other hand, the relatively higher contribution of the $d$ parameter to the uncertainty of $\mathrm{Cd}$ indicates that further suppression of the signal drift in the measurement by ICP-MS might help to improve the precision of the $\mathrm{Cd}$ analysis. It is notable that the values of the relative $u_{\mathrm{c}}$ for $\mathrm{As}, \mathrm{Cd}, \mathrm{Fe}$, and $\mathrm{Zn}$ in Tables 6(a) and 6(b) were quite close to one another in a narrow range from $0.82 \%$ for $\mathrm{Cd}$ to $1.27 \%$ for $\mathrm{Zn}$ despite that the elemental concentrations were different by three orders of magnitude.

\section{Application of the present method to various CRMs issued by NMIJ}

The present work had been applied to various CRMs issued by NMIJ, including tap water, milk powder, and tea leave powder, the results for which are summarized in Tables 7 to 9, respectively. In Tables 7 to 9 , it is notable that the results for the elements given over the dashed lines were those with relatively higher concentrations, i.e. the matrix, in each sample.

The maximum of elemental concentrations listed in Tables 7 to 9 were $c a .33 \mathrm{mg} \mathrm{kg}^{-1}$ of $\mathrm{Na}, c a .9 \mathrm{~g} \mathrm{~kg}^{-1}$ of Ca, and $2 \%$ of $\mathrm{K}$, respectively. Regardless of the apparent differences in the concentration levels of the matrix elements, the observed value for each element agreed with the certified value in the range of the expanded uncertainty in Tables 7 to 9 . These results indicate that the present method was valid for accurate measurements of the elements in samples with various matrix.

\section{Conclusions}

SAM based on a gravimetric sample preparation could be an effective approach for the removal or cancelling of matrix effects in measurements by ICP-MS. The concentration of an
Table 8 Analytical results of the elements in NMIJ CRM 7512-a (milk powder)

\begin{tabular}{|c|c|c|c|}
\hline \multirow{2}{*}{ Element $^{\mathrm{a}}$} & Observed value & Certified value & \multirow{2}{*}{ Unit } \\
\hline & Mean $\pm U$ & Mean $\pm U$ & \\
\hline${ }^{40} \mathrm{Ca}\left({ }^{24} \mathrm{Mg}\right)$ & $8.75 \pm 0.32$ & $8.65 \pm 0.38$ & $\mathrm{~g} \mathrm{~kg}^{-1}$ \\
\hline${ }^{39} \mathrm{~K}\left({ }^{24} \mathrm{Mg}\right)$ & $8.39 \pm 0.31$ & $8.41 \pm 0.33$ & $\mathrm{~g} \mathrm{~kg}^{-1}$ \\
\hline${ }^{24} \mathrm{Mg}\left({ }^{40} \mathrm{Ca}\right)$ & $0.823 \pm 0.010$ & $0.819 \pm 0.024$ & $\mathrm{~g} \mathrm{~kg}^{-1}$ \\
\hline${ }^{23} \mathrm{Na}\left({ }^{40} \mathrm{Ca}\right)$ & $1.89 \pm 0.04$ & $1.87 \pm 0.09$ & $\mathrm{~g} \mathrm{~kg}^{-1}$ \\
\hline${ }^{31} \mathrm{P}\left({ }^{44} \mathrm{Ca}\right)$ & $5.46 \pm 0.01$ & $5.62 \pm 0.23$ & $\mathrm{~g} \mathrm{~kg}^{-1}$ \\
\hline${ }^{137} \mathrm{Ba}\left({ }^{57} \mathrm{Fe}\right)$ & $0.441 \pm 0.007$ & $0.449 \pm 0.013$ & $\mathrm{mg} \mathrm{kg}^{-1}$ \\
\hline${ }^{63} \mathrm{Cu}\left({ }^{57} \mathrm{Fe}\right)$ & $4.66 \pm 0.22$ & $4.66 \pm 0.23$ & $\mathrm{mg} \mathrm{kg}^{-1}$ \\
\hline${ }^{56} \mathrm{Fe}\left({ }^{44} \mathrm{Ca}\right)$ & $100.7 \pm 1.3$ & $104 \pm 7$ & $\mathrm{mg} \mathrm{kg}^{-1}$ \\
\hline${ }^{55} \mathrm{Mn}\left({ }^{57} \mathrm{Fe}\right)$ & $0.917 \pm 0.011$ & $0.931 \pm 0.032$ & $\mathrm{mg} \mathrm{kg}^{-1}$ \\
\hline${ }^{98} \mathrm{Mo}\left({ }^{66} \mathrm{Zn}\right)$ & $0.221 \pm 0.006$ & $0.223 \pm 0.012$ & $\mathrm{mg} \mathrm{kg}^{-1}$ \\
\hline${ }^{85} \mathrm{Rb}\left({ }^{66} \mathrm{Zn}\right)$ & $8.86 \pm 0.08$ & $8.93 \pm 0.31$ & $\mathrm{mg} \mathrm{kg}^{-1}$ \\
\hline${ }^{88} \mathrm{Sr}\left({ }^{66} \mathrm{Zn}\right)$ & $5.76 \pm 0.06$ & $5.88 \pm 0.20$ & $\mathrm{mg} \mathrm{kg}^{-1}$ \\
\hline${ }^{66} \mathrm{Zn}\left({ }^{44} \mathrm{Ca}\right)$ & $41.4 \pm 0.4$ & $41.3 \pm 1.4$ & $\mathrm{mg} \mathrm{kg}^{-1}$ \\
\hline
\end{tabular}

a. An element in the brackets is the internal standard element.

Table 9 Analytical results of the elements in NMIJ CRM 7505-a (tea leave powder)

\begin{tabular}{|c|c|c|c|}
\hline \multirow{2}{*}{ Element $^{\mathrm{a}}$} & Observed value & Certified value & \multirow{2}{*}{ Unit } \\
\hline & Mean $\pm U$ & Mean $\pm U$ & \\
\hline${ }^{40} \mathrm{Ca}\left({ }^{27} \mathrm{Al}\right)$ & $0.444 \pm 0.001$ & $0.450 \pm 0.013$ & $\%$ \\
\hline${ }^{39} \mathrm{~K}\left({ }^{24} \mathrm{Mg}\right)$ & $1.56 \pm 0.01$ & $1.59 \pm 0.04$ & $\%$ \\
\hline${ }^{24} \mathrm{Mg}\left({ }^{27} \mathrm{Al}\right)$ & $0.295 \pm 0.001$ & $0.301 \pm 0.008$ & $\%$ \\
\hline${ }^{31} \mathrm{P}\left({ }^{27} \mathrm{Al}\right)$ & $0.334 \pm 0.004$ & $0.339 \pm 0.009$ & $\%$ \\
\hline${ }^{27} \mathrm{Al}\left({ }^{24} \mathrm{Mg}\right)$ & $719 \pm 3$ & $709 \pm 23$ & $\mathrm{mg} \mathrm{kg}^{-1}$ \\
\hline${ }^{11} \mathrm{~B}\left({ }^{55} \mathrm{Mn}\right)$ & $20.3 \pm 0.2$ & $19.7 \pm 0.9$ & $\mathrm{mg} \mathrm{kg}^{-1}$ \\
\hline${ }^{137} \mathrm{Ba}\left({ }^{55} \mathrm{Mn}\right)$ & $20.2 \pm 0.1$ & $20.4 \pm 0.7$ & $\mathrm{mg} \mathrm{kg}^{-1}$ \\
\hline${ }^{110} \mathrm{Cd}\left({ }^{63} \mathrm{Cu}\right)$ & $0.0139 \pm 0.0007$ & $0.0139 \pm 0.0011$ & $\mathrm{mg} \mathrm{kg}^{-1}$ \\
\hline${ }^{63} \mathrm{Cu}\left({ }^{55} \mathrm{Mn}\right)$ & $19.2 \pm 0.1$ & $19.2 \pm 0.6$ & $\mathrm{mg} \mathrm{kg}^{-1}$ \\
\hline${ }^{56} \mathrm{Fe}\left({ }^{55} \mathrm{Mn}\right)$ & $81.9 \pm 0.4$ & $82.1 \pm 2.4$ & $\mathrm{mg} \mathrm{kg}^{-1}$ \\
\hline${ }^{7} \mathrm{Li}\left({ }^{63} \mathrm{Cu}\right)$ & $0.57 \pm 0.02$ & $0.57 \pm 0.04$ & $\mathrm{mg} \mathrm{kg}^{-1}$ \\
\hline${ }^{55} \mathrm{Mn}\left({ }^{24} \mathrm{Mg}\right)$ & $748 \pm 1$ & $760 \pm 22$ & $\mathrm{mg} \mathrm{kg}^{-1}$ \\
\hline${ }^{23} \mathrm{Na}\left({ }^{63} \mathrm{Cu}\right)$ & $7.3 \pm 0.2$ & $7.2 \pm 0.5$ & $\mathrm{mg} \mathrm{kg}^{-1}$ \\
\hline${ }^{60} \mathrm{Ni}\left({ }^{55} \mathrm{Mn}\right)$ & $5.45 \pm 0.05$ & $5.5 \pm 0.3$ & $\mathrm{mg} \mathrm{kg}^{-1}$ \\
\hline${ }^{208} \mathrm{~Pb}\left({ }^{63} \mathrm{Cu}\right)$ & $0.094 \pm 0.003$ & $0.094 \pm 0.006$ & $\mathrm{mg} \mathrm{kg}^{-1}$ \\
\hline${ }^{85} \mathrm{Rb}\left({ }^{55} \mathrm{Mn}\right)$ & $7.1 \pm 0.1$ & $7.2 \pm 0.4$ & $\mathrm{mg} \mathrm{kg}^{-1}$ \\
\hline${ }^{88} \mathrm{Sr}\left({ }^{55} \mathrm{Mn}\right)$ & $9.1 \pm 0.1$ & $9.0 \pm 0.3$ & $\mathrm{mg} \mathrm{kg}^{-1}$ \\
\hline${ }^{66} \mathrm{Zn}\left({ }^{55} \mathrm{Mn}\right)$ & $23.2 \pm 0.1$ & $22.7 \pm 0.7$ & $\mathrm{mg} \mathrm{kg}^{-1}$ \\
\hline${ }^{59} \mathrm{Co}\left({ }^{63} \mathrm{Cu}\right)$ & $0.254 \pm 0.006$ & $(0.257 \pm 0.011)^{\mathrm{b}}$ & $\mathrm{mg} \mathrm{kg}^{-1}$ \\
\hline
\end{tabular}

a. An element in the brackets is the internal standard element. b. Reference value.

element could be calculated based on the element/internalstandard signal intensity ratio in spiked and non-spiked samples. The present method is valid for the analysis of elements in various kinds of matrix, confirmed by the international comparisons covering bioethanol, human serum, biodiesel fuel, drinking water, infant formula milk power, and seafood. The analytical results for three CRMs, i.e. tap water, milk powder, and tea leave powder, indicate that the present method might be applied to the analysis of samples with a wide range of concentration range for matrix elements.

\section{Acknowledgements}

The present work was partly supported by the National Natural Science Foundation of China (Grant No. 41406093). 


\section{References}

1. S. Carter, A. Fisher, B. Gibson, J. Marshal, and B. Russell, J. Anal. At. Spectrom., 2017, 32, 2068.

2. O. T. Butler, W. R. L. Cairns, J. M. Cook, and C. M. Davidson, J. Anal. At. Spectrom., 2017, 32, 11.

3. A. Taylor, N. Barlow, M. P. Day, S. Hill, and M. Patriarca, J. Anal. At. Spectrom., 2017, 32, 432.

4. E. H. Evans, J. Pisonero, C. M. M. Smith, and R. N. Taylor, J. Anal. At. Spectrom., 2017, 32, 869.

5. C. Agatemor and D. Beauchemin, Anal. Chim. Acta, 2011, 706, 66.

6. S. H. Tan and G. Horlick, J. Anal. At. Spectrom., 1987, 2, 745 .

7. G. G. Guilbault and M. Hjelm, Pure Appl. Chem., 1989, 61, 1657.

8. S. L. R. Ellison and M. Thompson, Analyst, 2008, 133, 992.

9. A. Makishima and E. Nakamura, Geostand. Newslett. J. Geostand. Geoanal., 1997, 21, 307.

10. G. Xiao and D. Beauchemin, J. Anal. At. Spectrom., 1994, 9, 509.

11. C. Agatemor and D. Beauchemin, Spectrochim. Acta, Part $B, \mathbf{2 0 1 1}, 66,1$.

12. K. Hu and R. S. Houk, J. Am. Soc. Mass Spectrom., 1993, 4, 28.

13. N. Praphairaksit and R. S. Houk, Anal. Chem., 2000, 72, 4435.

14. S. H. Nam, W. R. L. Masamba, and A. Montaser, Spectrochim. Acta, Part B, 1994, 49, 12.

15. G. Xiao and D. Beauchemin, Canadian J. Anal. Sci. Spectrosc., 2001, 46, 28.

16. V. K. Karandashev, A. Y. Leykin, and K. V. Zhernokleeva, J. Anal. Chem., 2014, 69, 22.

17. S. Q. Cao, H. T. Chen, X. J. Zeng, and D. P. Wang, Chin. J. Anal. Chem., 2000, 28, 1476.

18. J. Z. Kang, T. C. Duan, P. R. Guo, C. Wang, H. T. Chen, and X. J. Zeng, Chem. J. Chin. Univ., 2004, 25, 252.

19. N. Praphairaksit and R. S. Houk, Anal. Chem., 2000, 72, 2351.

20. P. Richner, J. Anal. At. Spectrom., 1993, 8, 927.

21. C. T. Gross, S. M. McIntyre, and R. S. Houk, Anal. Chem., 2009, 81, 4898.

22. M. He, B. Hu, and Z. C. Jiang, Chem. J. Chin. Univ., 2004, 25, 2232.

23. H. Kumagai, M. Yamanaka, T. Sakai, T. Yokoyama, T. M. Suzuki, and T. Suzuki, J. Anal. At. Spectrom., 1998, 13, 579 .

24. T. C. Duan, X. J. Song, P. R. Guo, H. F. Li, L. H. Pan, H. T. Chen, and J. W. Xu, J. Anal. At. Spectrom., 2007, 22, 403.

25. Z. T. Wang, J. Zheng, L. G. Cao, K. Tagami, and S. Uchida, Anal. Chem., 2016, 88, 7387.

26. A. S. Al-Ammar, E. Reitznerova, and R. M. Barnes, Spectrochim. Acta, Part B, 1999, 54, 1813.

27. A. S. Al-Ammar. R. K. Gupta, and R. M. Barnes, Spectrochim. Acta, Part B, 1999, 54, 1849.

28. M. Willbold and K. P. Jochum, Geostand. Geoanal. Res., 2005, 29, 63.

29. T. Moriguti, A. Makishima, and E. Nakamura, Geostand. Geoanal. Res., 2004, 28, 371.

30. H. Wildner and G. Wunsch, Fresenius J. Anal. Chem., 1996, 354, 807.

31. S. H. Hu, S. L. Lin, Y. Y. Liu, and S. Gao, Chem. J. Chin.
Univ., 2000, 21, 368.

32. K. Danzer and L. A. Currie, Pure Appl. Chem., 1998, 70, 993.

33. S. J. Christopher, E. L. Kilpatrick, L. L. Yu, W. C. Davis, and B. M. Adair, Talanta, 2012, 88, 749.

34. D. Hare, C. Austin, and P. Doble, Analyst, 2012, 137, 1527.

35. I. F. Seregina, S. Y. Lanskaya, O. I. Okina, M. A. Bol'shov, S. M. Lyapunov, O. L. Chugunova, and A. S. Foktova, J. Anal. Chem., 2010, 65, 964.

36. Y. B. Dan, H. L. Shi, C. Stephan, and X. H. Liang, Mirochem. J., 2015, 122, 119.

37. W. N. Chen, S. J. Jiang, Y. L. Chen, and A. C. Sahayam, Anal. Chim. Acta, 2015, 860, 8.

38. Y. T. Li, S. J. Jiang, Y. L. Chen, and A. C. Sahayam, J. Anal. At. Spectrom., 2014, 29, 2176.

39. M. Krachler, R. Alvarez-Sarandes, and S. Van Winckel, $J$. Anal. At. Spectrom., 2014, 29, 817.

40. M. Krachler, R. Alvarez-Sarandes, and S. Van Winckel, $J$. Anal. At. Spectrom., 2013, 28, 114.

41. B. K. Nagar, A. Saha, S. B. Deb, and M. K. Saxena, At. Spectrosc., 2014, 35, 187.

42. Y. Zhu and A. Itoh, Anal. Sci., 2016, 32, 1301.

43. W. H. Hsu, S. J. Jiang, and A. C. Sahayam, Anal. Chim. Acta, 2013, 794, 15.

44. O. J. Rouxel and M. Auro, Geostand. Geoanal. Res., 2010, 34, 135.

45. S. Y. Huang, S. J. Jiang, and A. C. Sahayam, Spectrochim. Acta, Part B, 2014, 101, 46.

46. W. H. Hsu, S. J. Jiang, and A. C. Sahayam, Talanta, 2013, 117, 268.

47. Y. Zhu and K. Chiba, J. Anal. At. Spectrom., 2012, 27, 1000.

48. R. M. Gaschnig, R. L. Rudnick, and W. F. McDonough, Geostand. Geoanal. Res., 2015, 39, 371.

49. T. D. Yokoyama, T. Suzuki, Y. Kon, and T. Hirata, Anal. Chem., 2011, 83, 8892.

50. J. Prytulak, S. G. Nielsen, and A. N. Halliday, Geostand. Geoanal. Res., 2011, 35, 307.

51. A. Virgilio, D. Schiavo, L. M. Costa, J. A. Nobrega, B. T. Jones, and G. L. Donati, Talanta, 2016, 161, 826.

52. W. Yuan, J. B. Chen, J. L. Birck, Z. Y. Yin, S. L. Yuan, H. M. Cai, Z. W. Wang, Q. Huang, and Z. H. Wang, Anal. Chem., 2016, 88, 9606.

53. J. S. Lee and H. B. Lim, J. Anal. At. Spectrom., 2011, 26, 1534.

54. H. P. Mi, H. M. Zhu, G. R. Li, X. Yu, B. B. Ma, X. L. Zhou, Y. S. Wang, Z. H. Su, and X. Deng, Spectrosc. Spect. Anal., 2017, 37, 646.

55. C. C. Chen, S. J. Jiang, and A. C. Sahayam, Talanta, 2015, 131,585 .

56. T. Falta, P. Heffeter, A. Mohamed, W. Berger, S. Hann, and G. Koellensperger, J. Anal. At. Spectrom., 2011, 26, 109.

57. A. Hanc, A. Malecka, A. Kutrowska, A. BangniewskaZadworna, B. Tomaszewsk, and D. Baralkiewicz, Mirochem. J., 2016, 128, 305.

58. M. L. Lin and S. J. Jiang, Food Chem., 2013, 141, 2158.

59. Y. Zhu, A. Hioki, and K. Chiba, Anal. Sci., 2013, 29, 1027.

60. W. R. Kelly, K. W. Pratt, W. E. Guthrie, and K. R. Martin, Anal. Bioanal. Chem., 2011, 400, 1805.

61. W. J. Campbell and H. F. Carl, Anal. Chem., 1954, 26, 800.

62. Y. Zhu, A. Hioki, and K. Chiba, J. Anal. At. Spectrom., 2013, 28, 883 .

63. JIS3505:1994, "Volumetric Glassware", Japanese Industrial Standards Committee, Tokyo, Japan.

64. Y. Zhu, T. Narukawa, K. Inagaki, T. Kuroiwa, and K. Chiba, 
Anal. Sci., 2011, 27, 1149.

65. JCGM100:2008, "Evaluation of Measurement Data-Guide to the Expression of Uncertainty in Measurement", Joint Committee for Guides in Metrology (JCGM), Sèvres, France.

66. L. Valiente, J. W. Bennett, R. C. de Sena, B. Kotzeva, G. Massiff, J. Chao, R. Nasr, G. Labarraque, E. K. E. Lampi, D. W. Sin, C. Mok, S. Wong, Y. Yip, S. Gopala, A. Prabhat, K. Gupta, Y. Zhu, Y. Yim, O. Zakaria, J. Velina, L. Manzano, R. Shin, M. Horvat, and C. Yafa, Metrologia, 2013, 50, Tech. Suppl., 08004.

67. T. Zhou, E. Kakoulides, Y. Zhu, R. Jaehrling, O. Rienitz, D. Saxby, P. Phukphatthanachai, C. Yafa, G. Labarraque, O. Cankur, S. Z. Can, L. A. Konopelko, Yu, A, Kustikov, R. C. de Sena, J. M. Rodrigues, G. F. Sarmanho, W. F. de Carvalho Rocha, and L. A. dos Reis, Metrologia, 2014, 51, Tech. Suppl., 08013.

68. T. Narukawa, Y. Zhu, F. Wai-Hong, Y. Ho-Pan, C. Swart, O. Rienitz, A. Işleyen, M. Tunc, S. Z. Can, N. Tokman, R. Shin, P. Phukphatthanachai, C. Yafa, E. Kakoulides, L. Feng, S. Hill, P. Fisicaro, M. E. del Castillo, and S. Long, Metrologia, 2016, 53, Tech. Suppl., 08008.

69. T. Kuroiwa, Y. Zhu, K. Inagaki, D. Saxby, I. White, J. Merrick, T. Araujo, M. Almeida, J. Rodrigues, L. Yang, I. G. Pihillagawa, Z. Mester, S. S. Riquelme, L. Pérez, R. Barriga, C. Núñez, J. Chao, J. Wang, Q. Wang, N. Shi, Hai
Lu, P. Song, T. Näykki, T. Sara-Aho, G. Labarraque, C. Oster, O. Rienitz, R. Jährling, C. Pape, E. Lampi, E. Kakoulides, W. H. Fung, H. S. Chu, R. Ketrin, E. Mardika, I. Komalasari, T. Okumu, J. N. Kang'iri, Y.-H. Yim, S. W. Heo, K.-S. Lee, J. K. Suh, Y. Lim, C. Uribe, E. Carrasco, E. D. Tayag, A. R. C. Dablio, E. K. P. E. L. Damian, L. Konopelko, A. Krylov, S. Vadim, R. Shin, S. L. Peng, W. Juan, X. Chang, F. Dewi, M. Horvat, T. Zuliani, S. Taebunpakul, C. Yafa, N. Kaewkhomdee, U. Thiengmanee, S. Z. Can, B. Ari, O. Cankur, E. Ferreira, R. Pérez, S. E. Long, B. L. Kassim, K. E. Murphy, J. L. Molloy, and T. A. Butler, Metrologia, 2017, 54, Tech. Suppl., 08012.

70. J. Merrick, D. Saxby, E. S. Dutra, R. C. de Sena, T. de Oliveira Araújo, M. D. de Almeida, L. Yang, I. G. Pihillagawa, Z. Mester, S. Sandoval, C. Wei, M. E. D. Castillo, C. Oster, P. Fisicaro, O. Rienitz, C. Pape, U. Schulz, R. Jährling, V. Görlitz, E. Lampi, E. Kakoulides, D. W. Sin, Y.-C. Yip, Y.-T. Tsoi, Y. Zhu, T. O. Okumu, Y. Yim, S. W. Heo, M. Han, Y. Lim, M. A. Osuna, L. Regalado, C. Uribe, M. M. Buzoianu, S. Duta, L. Konopelko, A. Krylov, R. Shin, M. Linsky, A. Botha, B. Magnusson, C. Haraldsson, U. Thiengmanee, H. Klich, S. Z. Can, F. G. Coskun, M. Tunc, J. Entwisle, J. O’Reilly, S. Hill, H. Goenaga-Infante, M. Winchester, S. A. Rabb, and R. Pérez-Zambra, Metrologia, 2017, 54, Tech. Suppl., 08013. 